\title{
RISK ASSESSMENT OF ACCIDENTAL FIRE BREAKDOW IN A RESIDENTIAL AREA OF KHULNA CITY, BANGLADESH
}

\author{
Sadia Shama, Alif Sanim Shurid and Md. Nazmul Haque* \\ Department of Urban and Regional Planning, Khulna University of Engineering \& Technology, Khulna-9203 \\ Bangladesh
}

Received: 18 April 2021

Accepted: 27 June 2021

\begin{abstract}
The research aimed at determining the risk of fire hazard of the settlements in the area of Khalishpur, Khulna which is close to three oil depots and two power stations. The maintainence of land use zonal variance is completely absent in this area. The research has followed four stages. First, ptrliminary study was done for choosing the most vulnerable samples, then the factors for identifying the risk index are considered on the basis of hazard, vulnerability and exposure. After collecting the required primary and secondary data, the Analytical Hierarchy Process (AHP) method is used to identify the weightage of each of those sub-factors. Then the risk equation is used to identify the risk level of each buildings and a map is prepared by using their coordinates and risk level. The study states that, 55\% of the total samples are in the medium risk profile.
\end{abstract}

Keywords: Accidental fire breakdown, Analytical Hierarchy Process, Focus group discussion; Land use zonal variances.

\section{INTRODUCTION}

According to the Society for Risk Analysis, the definition of risk is one that varies from area to area and even between members in the same area (Watts \& Hall, 2002). Risk is the potential for realization of unwanted, adverse consequences to human life, health, property, or the environment. Estimation of risk (for an event) is usually based on the expected value of the conditional probability of the event occurring times the consequence of the event, given that it has occurred. Before quantitatively assessing fire risk, it is essential to determine its measure (Hadjisophocleous, 2003). As Bukowski (1996) mentioned, it is difficult to express risk to life in a way that can be understood by the public. At this edge of $21^{\text {st }}$ century, urbanization has accelerated to such a rapid pace. About 1 billion people are residents of urban area over the world and are yet the most vulnerable towards disasters as cyclones, earthquakes, fire, flood, crime, industrial accidents and many more (Disaster Report, 2014). According to the World Disasters Report (2010), flood, earthquakes, cyclones are categorized as urban disaster whereas fire hazard or explosions are more of a technological hazard.

Oil depots are the store house to a lot of flammable petroleum products. By chance the fuel and air comes in contact or stored fuel gets ignited somehow there is a high possibility that in may turn to a huge fire explosion. Building fire risk analysis can be considered as the process of understanding and characterizing fire hazard in a building, unwanted outcomes that may result from a fire, and the likelihood of fire and unwanted outcomes occurring (Meacham et al., 2016). Also while regular maintenance like cleaning or nearby activities like cooking, welding, industries etc. these might be a reason to accidentally trigger a fire explosion causing great casualties, heavy environmental pollution and massive economic losses as well. For the past few years, a series of large fire and explosion accidents were happened in oil depots all the world around, such as the Buncefield oil depot explosion in London (Zhou et al., 2016). In December 2005 an accident was occur in Buncefield, $40 \mathrm{~km}$ northwest of London, which caused a drastic disruption in the environment as well as in the economy. This accident cause resettlement of about 2000 people, reconstruction of about $29 \mathrm{~km}$ of road, relocation of nearby businesses, pollution of groundwater and many other environmental impacts (Atkinson, 2014). Building fire risk differentiates life risks into two categories, these are societal risk and individual risk (Frantzich, 1998). The individual risk is defined as the risk, towards which any particular occupant is at a vulnerable position due to aspecific reason (Frantzich, 1998).

Talking about Bangladesh, in recent years Bangladesh has faced several massive fire and explosion hazards and has very poor management quality to meet the necessary qualification to prevent the hazards. A statistics state that on an average 53 fire accidents were occured daily in Bangladesh in the year 2018 (Hossain, 2019). Among the cities of Bangladesh, Dhaka faced 2334, Chittagong faced 1735 and Khulna faced 1041 occurrences in the 
same year (Disaster Report, 2014). Though there is several different international and national guidelines,acts, policies and plans exist regarding this human induced disaser. Some examples are Safety Guidelines and Good Industry Practices for Oil Terminals by United Nations, National Plan for Disaster Management (2016-2020) by Ministry of Disaster Management and Relief of Bangladesh, Industrial Policy 2005 by Ministry of Industries of Bangladesh, Law for Fire Prevention, Extinguishment and Rescue by Bangladesh Government etc. In a study it is found that most of the accidental firebreakdowns arise in Bangladesh due to unplanned development of urban areas, lack of fire management system and the amount of losses heightened because of ineffectiveness of mitigation measurs like narrow roads, absence or narrow emergency exits point, inadequate number of fire stations etc (Islam and Hossain, 2018). An accident was triggered by the explosion of electric tranformer and was then fanned due to the explosive liquids that are stored nearby in in the Nimtali area of Old Dhaka in 2010. This incident was named as Nimtali Tragedy and results in the death of 117 local residents and injury of more than 100 people (Imam, 2010).

Khulna City being the heart of the south-western part of the country and due to the recent communication development with the south west, rapid pace in urbanization in Khulna city is being seen in recent years. Therefore, the risk of fire hazard is increasing day by day. The way to reduce such risk is to assess the vulnerability of areas with heavy industries, oil depots, densely populated areas etc. In this study, risk index is used to determine the risk level of each the selected buildings and can be defined as a function of hazard, vulnerability and exposure. In terms of planning, hazard can be defined as any event, phenomenon and/or human activity which has the potential or capability to cause an interruption or disturbance to people's life including injury even loss of life, property damage and economic loss, environmetal degration etc (UNDRR, 2017). Here hazard index is used to determine the probability of occurance of accidental fire breakdown on and around each of the selected buildings (UNDRR, 2017) and vulnerability index can be used to identify the coping capacity of each of the selected buildings in case of accidental fire breakdown. Element at risk index helps to determine the quantity of element like people's life, property etc that are under risk. Under each of these index, there are several components and sub-components. After a rigorous literature review of similar kinds of study (Keane et al., 2008; Cardona et al., 2012; Hu et al., 2018; Shi et al., 2014; Sakib et al., 2010; Haque et al., 2021) and expert opinion survey, components and subcomponents under each index are fixed.

Analytical Hierarchy Process (AHP) is used to weight the factors considered responsible to trigger a fire hazard and Geographic Information System (GIS) is used to overlay those and generate a map showing the radius of area under risk due to the presence of the fire risk factor.The Analytic Hierarchy Process (AHP) is widely used by decision makers and researchers. The definition of criteria and the calculation of their weight are central in this method to assess the alternatives. However, there are few studies that focus on them (Camanho and Russo, 2015).

Ward boundary is the smallest possible unit to define an urban area in Bangladesh, though several studies on accidental fire breakdown were conducted earlier but none of those studies were carried out at ward level. As the study is conducted at ward level it need to address all the possible factors at micro level. Further, from the perspective of landuse planning, it is very necessary to maintain landuse zonal variance especially for this type of risky landuse. But it is completely absent in the selected study area. For the safety and well-being of the residents of the selected area, this research is found to be very vital.

This study is conducted in Khalishpur, Khulna as there are presence of oil depots and also residential and commercial mixed land-use at a very low distance making them the most vulnerable group. As a whole the study is conducted to determine the risk under which currently the residents of ward no. 07 and 08 are in due to not maintaining the land use zonal variance and still growing residence beside such a risky land use zone.

\section{METHODOLOGY}

The research focuses at risk assessment for fire hazard in the residential area of word no 07 of Khulna City Corporation. At first the risk function was studied and then the sub factors and element under the main factors were fixed.

\subsection{Study Area}

At a present scenario Khulna is the third largest city in Bangladesh and one of the largest economic hubs of the country, therefore fire hazard assessment to be able take necessary measures is unavoidably important. Khulna has faced a total of 190 massive fire incidents from years 2014-2017. In 2014 there were 29 incidents. In 2015 it was 27, in 2016 it was 67 and in 2017 it was 69, which shows the fire hazard occurrence rate is increasing at an alarming rate (Bangladesh Fire Service and Civil Defense, 2018). Due to mixed and unplanned land-use, the study area selected is Ward no 07 of Khulna city, having 3 massive oil depots and 1 power station just adjacent to residential area. A $225 \mathrm{MW}$ power station close to an oil depot, a simple shot circuit fire will be able to create a 
massive disaster. The study area is of 0.404 sq. km (Source: Khulna City Corporation, 2019), having a population of 18,000 (Bangladesh Bureau of Statistics, 2001). Figure1 represents the map of the study area while Table 1 shows the detain description of the study area.

Table 1: Study Area Details.

\begin{tabular}{lc}
\hline \multicolumn{1}{c}{ Location } & Ward no-07, KCC \\
\hline Area (in sq. m) & 404000 \\
Name of localities and mohallas & Uttar Kashipur, Kashipur Meghna Road, Padma Road and Khalishpur \\
& Kabarkhana Road \\
Population & 18,000 \\
Population Density (per acre) & 73 \\
Sex Ratio (M/F) *100 & 114.142 \\
Household & 2594 \\
Literacy Rate $(\%)$ & 64.50 \\
\hline
\end{tabular}

(Source:Roy, 2013)

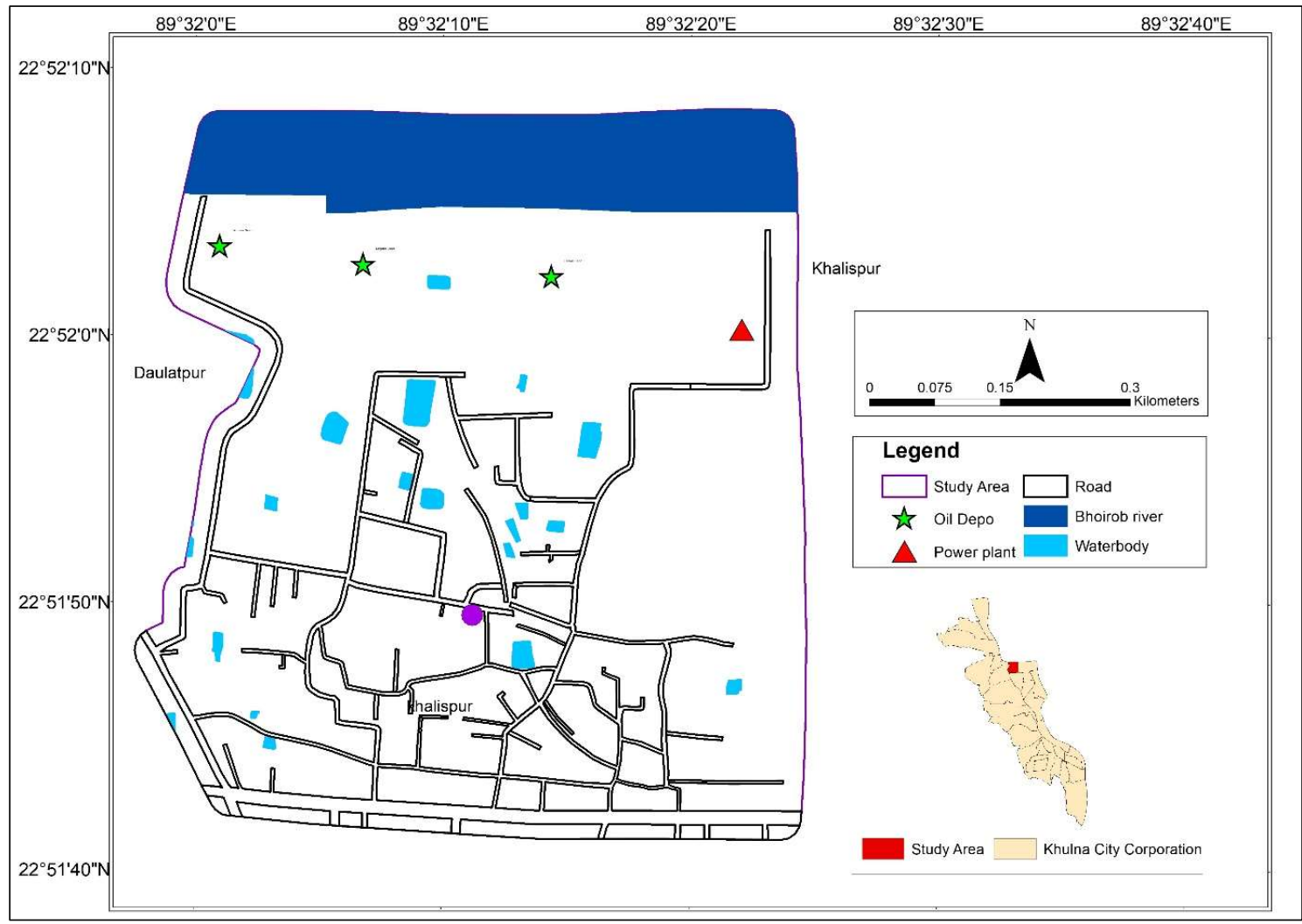

Figure 1: Map of the Study Area

\subsection{Data Collection}

For primary data collection, field survey was the most suitable and relevant process. Field survey was performed in two parts:

- Questionnaire survey and focus group discussion

- GPS coordinate marking.

For questionnaire survey of the household the sample size is determined by using the given equation:

$$
N=\left(\frac{Z \sigma}{E}\right)^{2}
$$

Where $n$ be the sample size, $Z$ be the critical value of the normal distribution, $\sigma$ be the standard deviation and $\mathrm{E}$ be the difference between the observed and actual mean. For this study, 95\% significance level and 5\% error margin is used. Using this formula, the sample size was determined 75 households. 
Questionnaire survey was performed at 75 households of 20 residential buildings. After a preliminary survey, all the stakeholders of the study are identified and listed. A priority ranking is then conducted to find out the most exposed populations and as they are the most targeted population of this sudy during the questionaire survey they are focused most. The local residents were asked about the factors about fire hazard as well as warned to be cautious.Also secondary data were collected from $\mathrm{KCC}$ and the population from BBS. The local councilor, Town Planner of KDA, officials of fire stations and oil depots were interviewed as key informants.

\subsection{Method}

The analysis of the collected data is performed in two steps and finally display the output in a map. The first step is to select the indicators and determine their weightage and the second step is to use those indicators to determine the risk index using AHP method. Risk index is mainly used to identify the risk level of each of the previously selected buildings of the study area and can be defined as a function of hazard, vulnerability and exposure.

In this case AHP method is used for weighing the factors. Pairwise comparisons are made between the components as well as between the sub-components and the relative importance between each pair of decision alternatives and criteria is rated. Normalization Pair wise comparison matrix are then calculated for the components and each of the sub-components.

Normalize Value $=\frac{\text { Column Value of Pairwise Matrix }}{\text { Column Sum of Pairwise Matrix }}$

From those matrix criteria of the components and sub-components are calculated by using the given formula.

Criteria Weight $=\frac{\text { Rowsum of Normalize Matrix }}{\text { No. of Component }}$

The final step is consistency check to determine the consistency of the calculated weight (Camanho and Russo, 2015).

The hazard, vulnerability and exposure index of each of the selected buildings are then calculatted. Using the risk function, the risk index of the buildings are also calcutted and classified into 3 catagories according to their risk index. After the determination of risk status of the buildings, with the help of ArcGIS 10.5 the buildings will be pointed out with points on the map. The risk status of each of the buildings is displayed by usind a color code in a map.

\section{ANALYSIS AND FINDINGS}

Land use Zonal Variance is a major concern especially for risky land-uses adjacent to other regular land-uses. The study area consisting of 3 oil depots which stores massive amount of petroleum and also manual handling within the study area increases the risk of hazard. On the other hand, the power points located right next to the petroleum depots are on $225 \mathrm{MW}$ capacity which adds to the risk to trigger an explosion.

\subsection{Hazard Index}

From literature review and expert consultation, five components are selected for hazard index. They are :Distance from depot, Smoker by habit, Electric connection status, Cooking system and Distance from power station (Shi et al., 2014; Lin et al., 2012; Islam and Adri, 2008).

Sub-components of status of electric connection are legal connection and illegal connection and the subcomponents of cooking system are electric cooker, Stove, LPG and pyre. Using the Analytical Hierarchy Process the weight of each of the components and sub-components are determined. Table 2 shows the weight of each components and sub-components.

Finally the hazard index of a building is calculated by using the given formula.

Hazard Index $=\sum_{\mathrm{n}=1}^{20}$ Weight of sub component*Weight of component

According to the suggestions of the key informant of the study, the fire hazard index is classified into three categories, low (0.140-0.220), medium (0.220-0.300) and high (0.301-0.380). According to this classification, $25 \%$ buildings are at low level, $35 \%$ are at medium level and $40 \%$ are at highly hazardous. 
Table 2: Weights of Component and sub-component of hazard index

\begin{tabular}{cccc}
\hline Component & Sub-component & Weight & \\
& & Sub-component & Component \\
\hline Distance from Depot & $0-0.375$ & 0.1 & 0.421 \\
$(\mathrm{~km})$ & $0.376-0.75$ & 0.2 & \\
& $0.751-1.125$ & 0.3 & \\
Distance from power & $1.125-1.5$ & 0.4 & 0.244 \\
station & $0-0.5$ & 0.1 & \\
$(\mathrm{~km})$ & $0.51-1$ & 0.2 & \\
& $1.01-1.5$ & 0.3 & 0.080 \\
Cooking System & $1.51-2$ & 0.4 & \\
& Stove & 0.095 & \\
& LPG & 0.307 & 0.044 \\
No. of Smoker & Electric Cooker & 0.040 & \\
& Pyre & 0.557 & 0.211 \\
Electrical Connection & Legal Connection & 0.3 & \\
& 2 or more & 0.7 & 0.3 \\
\hline
\end{tabular}

\subsection{Vulnerability Index}

Six components are selected for vulnerability index. They are :Building type, Surrounding land-use,Fire station distance,Distance of hospital,Building storied and Fire Management System (Lin et al., 2012; Islam and Adri, 2008; Biswas and Haque, 2019).

Sub-components of building type are "pucca", "semi-pucca" and "katcha", the sub-components of surrounding landuse are residential building, commercial area, industrial area and vacant land and the sub component of fire management system are fire exist, fire extinguisher, both and none. Using the Analytical Hierarchy Process the weight of each of the components and sub-components are determined. Table 3 shows the weight of each component and sub-component of vulnerablity index.

Table 3: Weights of Component and sub-component of vulnerability index

\begin{tabular}{|c|c|c|c|}
\hline \multirow[t]{2}{*}{ Component } & \multirow[t]{2}{*}{ Sub component } & \multicolumn{2}{|c|}{ Weight } \\
\hline & & Sub-component & Component \\
\hline \multirow[t]{3}{*}{ Building Type } & Pucca & 0.2 & 0.351 \\
\hline & Semi-pucca & 0.3 & \\
\hline & Katcha & 0.5 & \\
\hline \multirow{3}{*}{$\begin{array}{l}\text { No. of Building } \\
\text { Storied }\end{array}$} & 1 & 0.1 & 0.067 \\
\hline & $2-4$ & 0.3 & \\
\hline & 5 or more & 0.6 & \\
\hline \multirow{8}{*}{$\begin{array}{c}\text { Distance From } \\
\text { Fire Station } \\
(\mathrm{km}) \\
\text { Surrounding } \\
\text { Landuse }\end{array}$} & $1-1.5$ & 0.2 & 0.102 \\
\hline & $1.51-2$ & 0.3 & \\
\hline & $2.01-2.5$ & 0.5 & \\
\hline & Residential Area & 0.218 & 0.205 \\
\hline & Commercial Area & 0.109 & \\
\hline & Industrial Area & 0.051 & \\
\hline & Vacant & 0.292 & \\
\hline & Waterbodies & 0.330 & \\
\hline \multirow{2}{*}{$\begin{array}{c}\text { Distance from } \\
\text { hospital } \\
(\mathrm{km})\end{array}$} & $2-2.5$ & 0.4 & 0.046 \\
\hline & $2.51-3$ & 0.6 & \\
\hline \multirow{4}{*}{$\begin{array}{c}\text { Fire management } \\
\text { System }\end{array}$} & Not Present & 0.5 & 0.229 \\
\hline & Fire Exist & 0.2 & \\
\hline & Fire Extinguisher & 0.2 & \\
\hline & Both & 0.1 & \\
\hline
\end{tabular}


Finally the vulnerability index of a building is calculated by using the given formula.

Vulnerability Index $=\sum_{\mathrm{n}=1}^{20}$ Weight of sub component*Weight of component

According to the suggestions of the key informant of the study, the vulnerability index is classified into three categories, low (0.15-0.233), medium (0.234-0.317) and high (0.318-0.4). According to this classification, 15\% buildings are at low level, $60 \%$ are at medium level and $25 \%$ are at highly vulnerable to fire risk.

\subsection{Element at Risk Index}

Four components are selected for risk element index. They are: Population size, population distribution, health condition and monetary property value (Biswas and Haque, 2019). Sub-components of population distribution are children, elderly and women and the sub-components of health condition are fit, problem in movement and incapable to move. Using the Analytical Hierarchy Process the weight of each of the components and subcomponents are determined. $25 \%$ buildings are at low level, $35 \%$ are at medium level and $40 \%$ are at high level. Table 4 shows the weight of each of the component and sub component of element at risk index.

Table 4: Weights of Component and sub-component of risk element index

\begin{tabular}{|c|c|c|c|}
\hline \multirow[t]{2}{*}{ Component } & \multirow[t]{2}{*}{ Sub component } & \multicolumn{2}{|c|}{ Weight } \\
\hline & & Sub-component & Component \\
\hline \multirow[t]{4}{*}{ Total Population } & $0-6$ & 0.1 & 0.490 \\
\hline & $7-12$ & 0.2 & \\
\hline & $13-18$ & 0.3 & \\
\hline & $19-24$ & 0.4 & \\
\hline \multirow[t]{4}{*}{ Population Distribution } & $1-2$ & 0.1 & 0.182 \\
\hline & $3-4$ & 0.2 & \\
\hline & $5-6$ & 0.3 & \\
\hline & 6 or more & 0.4 & \\
\hline \multirow[t]{3}{*}{ Health Condition } & Fit & 0 & 0.253 \\
\hline & Problem in movement & 0.3 & \\
\hline & Incapable to move & 0.7 & \\
\hline \multirow[t]{4}{*}{ Property Value } & $0-1$ & 0.1 & 0.074 \\
\hline & $1-2$ & 0.2 & \\
\hline & $2.1-5$ & 0.3 & \\
\hline & 5.1 or more & 0.4 & \\
\hline
\end{tabular}

Finally the element at index of a building is calculated by using the given formula.

Element at risk index $=\sum_{\mathrm{n}=1}^{20}$ Weight of sub component*Weight of component

The element at risk index is classified into three categories, low (0.140-0.220), medium (0.220-0.300) and high (0.301-0.380) on the basis of the suggestions of the key informant of the study.

\subsection{Risk Index}

To determine the risk index of the specified area risk function is mainly used in this study.

Risk $=$ Hazard $*$ Vulnerability $*$ Elements at risk (UNNOSA, 2019)

Table 5 shows the risk index and risk level of each of the 20 buildings. From the analysis of the collected data the final output showed that $25 \%$ of the buildings are at low risk, $55 \%$ of them are at medium and $20 \%$ of the buildings are at a extreme risky condition. Table 6 shows the classification of risk index. 
Table 5: Risk Level of 20 selected building

\begin{tabular}{|c|c|c|c|c|c|c|}
\hline $\begin{array}{l}\text { Building } \\
\text { No. }\end{array}$ & $\begin{array}{c}\text { Building } \\
\text { Coordinate }\end{array}$ & $\begin{array}{c}\text { Hazard } \\
\text { Index }\end{array}$ & $\begin{array}{l}\text { Vulnerability } \\
\text { Index }\end{array}$ & $\begin{array}{l}\text { Risk } \\
\text { Element } \\
\text { Index }\end{array}$ & $\begin{array}{l}\text { Risk } \\
\text { Index }\end{array}$ & $\begin{array}{l}\text { Hazard } \\
\text { Level }\end{array}$ \\
\hline 1 & $\begin{array}{l}22^{\circ} 52^{\prime} 00.6^{\prime \prime} \mathrm{N} \\
89^{\circ} 32^{\prime} 07.2^{\prime \prime} \mathrm{E}\end{array}$ & 0.146 & 0.297 & 0.149 & 0.0065 & Low \\
\hline 2 & $\begin{array}{l}22^{\circ} 51^{\prime} 56.7^{\prime \prime} \mathrm{N} \\
89^{\circ} 32^{\prime} 07.5^{\prime \prime} \mathrm{E}\end{array}$ & 0.185 & 0.283 & 0.195 & 0.0102 & Moderate \\
\hline 3 & $\begin{array}{l}22^{\circ} 51^{\prime} 55.6^{\prime \prime N} \\
89^{\circ} 31^{\prime} 58.7^{\prime \prime} \mathrm{E}\end{array}$ & 0.338 & 0.39 & 0.187 & 0.0247 & High \\
\hline 4 & $\begin{array}{l}22^{\circ} 51^{\prime} 53.2^{\prime \prime} \mathrm{N} \\
89^{\circ} 32^{\prime} 01.0^{\prime \prime} \mathrm{E}\end{array}$ & 0.234 & 0.288 & 0.111 & 0.0075 & Low \\
\hline 5 & $\begin{array}{l}22^{\circ} 51^{\prime} 47.4^{\prime \prime} \mathrm{N} \\
89^{\circ} 31^{\prime} 54.8^{\prime \prime} \mathrm{E}\end{array}$ & 0.242 & 0.393 & 0.176 & 0.0167 & Moderate \\
\hline 6 & $\begin{array}{l}22^{\circ} 51^{\prime} 44.7^{\prime \prime N} \\
89^{\circ} 31^{\prime} 56.7^{\prime \prime} \mathrm{E}\end{array}$ & 0.318 & 0.185 & 0.296 & 0.0174 & Moderate \\
\hline 7 & $\begin{array}{l}22^{\circ} 51^{\prime} 58.3^{\prime \prime} \mathrm{N} \\
89^{\circ} 31^{\prime} 58.2^{\prime \prime} \mathrm{E}\end{array}$ & 0.179 & 0.229 & 0.213 & 0.0087 & Low \\
\hline 8 & $\begin{array}{l}22^{\circ} 51^{\prime} 52.8^{\prime \prime} \mathrm{N} \\
89^{\circ} 31^{\prime} 57.4^{\prime \prime} \mathrm{E}\end{array}$ & 0.277 & 0.288 & 0.149 & 0.0119 & Moderate \\
\hline 9 & $\begin{array}{l}22^{\circ} 51 ' 51.6^{\prime \prime} \mathrm{N} \\
89^{\circ} 32^{\prime} 06.2^{\prime \prime} \mathrm{E}\end{array}$ & 0.197 & 0.31 & 0.307 & 0.0187 & Moderate \\
\hline 10 & $\begin{array}{l}22^{\circ} 51^{\prime} 57.0^{\prime \prime} \mathrm{N} \\
89^{\circ} 32^{\prime} 07.9^{\prime \prime} \mathrm{E}\end{array}$ & 0.168 & 0.286 & 0.119 & 0.0057 & Low \\
\hline 11 & $\begin{array}{l}22^{\circ} 51 ' 57.4^{\prime \prime} \mathrm{N} \\
89^{\circ} 32^{\prime} 05.0^{\prime \prime} \mathrm{E}\end{array}$ & 0.252 & 0.229 & 0.195 & 0.0113 & Moderate \\
\hline 12 & $\begin{array}{l}22^{\circ} 51^{\prime} 51.3^{\prime \prime} \mathrm{N} \\
89^{\circ} 32^{\prime} 10.3^{\prime \prime} \mathrm{E}\end{array}$ & 0.297 & 0.253 & 0.119 & 0.0089 & Low \\
\hline 13 & $\begin{array}{l}22^{\circ} 51^{\prime} 47.6^{\prime \prime} \mathrm{N} \\
89^{\circ} 32^{\prime} 12.6^{\prime \prime} \mathrm{E}\end{array}$ & 0.263 & 0.266 & 0.244 & 0.0171 & Moderate \\
\hline 14 & $\begin{array}{l}22^{\circ} 51^{\prime} 45.8^{\prime \prime} \mathrm{N} \\
89^{\circ} 32^{\prime} 09.7^{\prime \prime} \mathrm{E}\end{array}$ & 0.318 & 0.253 & 0.205 & 0.0165 & Moderate \\
\hline 15 & $\begin{array}{l}22^{\circ} 51^{\prime} 48.2^{\prime \prime} \mathrm{N} \\
89^{\circ} 32^{\prime} 13.1^{\prime \prime} \mathrm{E}\end{array}$ & 0.361 & 0.32 & 0.303 & 0.0350 & High \\
\hline 16 & $\begin{array}{l}22^{\circ} 51^{\prime} 58.5^{\prime \prime} \mathrm{N} \\
89^{\circ} 32^{\prime} 15.8^{\prime \prime} \mathrm{E}\end{array}$ & 0.336 & 0.273 & 0.213 & 0.0195 & Moderate \\
\hline 17 & $\begin{array}{l}22^{\circ} 51^{\prime} 52.7 " \mathrm{~N} \\
89^{\circ} 32^{\prime} 25.0^{\prime \prime} \mathrm{E}\end{array}$ & 0.266 & 0.307 & 0.195 & 0.0159 & Moderate \\
\hline 18 & $\begin{array}{l}22^{\circ} 51^{\prime} 44.9^{\prime \prime} \mathrm{N} \\
89^{\circ} 32^{\prime} 18.4^{\prime \prime} \mathrm{E}\end{array}$ & 0.378 & 0.253 & 0.327 & 0.0313 & High \\
\hline 19 & $\begin{array}{l}22^{\circ} 51^{\prime} 47.7^{\prime \prime} \mathrm{N} \\
89^{\circ} 32^{\prime} 11.4^{\prime \prime} \mathrm{E}\end{array}$ & 0.309 & 0.276 & 0.182 & 0.0155 & Moderate \\
\hline 20 & $\begin{array}{l}22^{\circ} 51^{\prime} 47.8^{\prime \prime} \mathrm{N} \\
89^{\circ} 32^{\prime} 07.8^{\prime \prime} \mathrm{E}\end{array}$ & 0.309 & 0.319 & 0.28 & 0.0276 & High \\
\hline
\end{tabular}


Tabel 6: Classification of Risk Index

\begin{tabular}{cccc}
\hline Risk Score Range & Risk Level & $\begin{array}{c}\text { Number of } \\
\text { Buildings }\end{array}$ & Parcentage \\
\hline $0-0.01$ & Low & 5 & 25 \\
$0.0101-0.02$ & Moderate & 11 & 55 \\
Above 0.02 & Extremly Risky & 4 & 20 \\
\hline
\end{tabular}

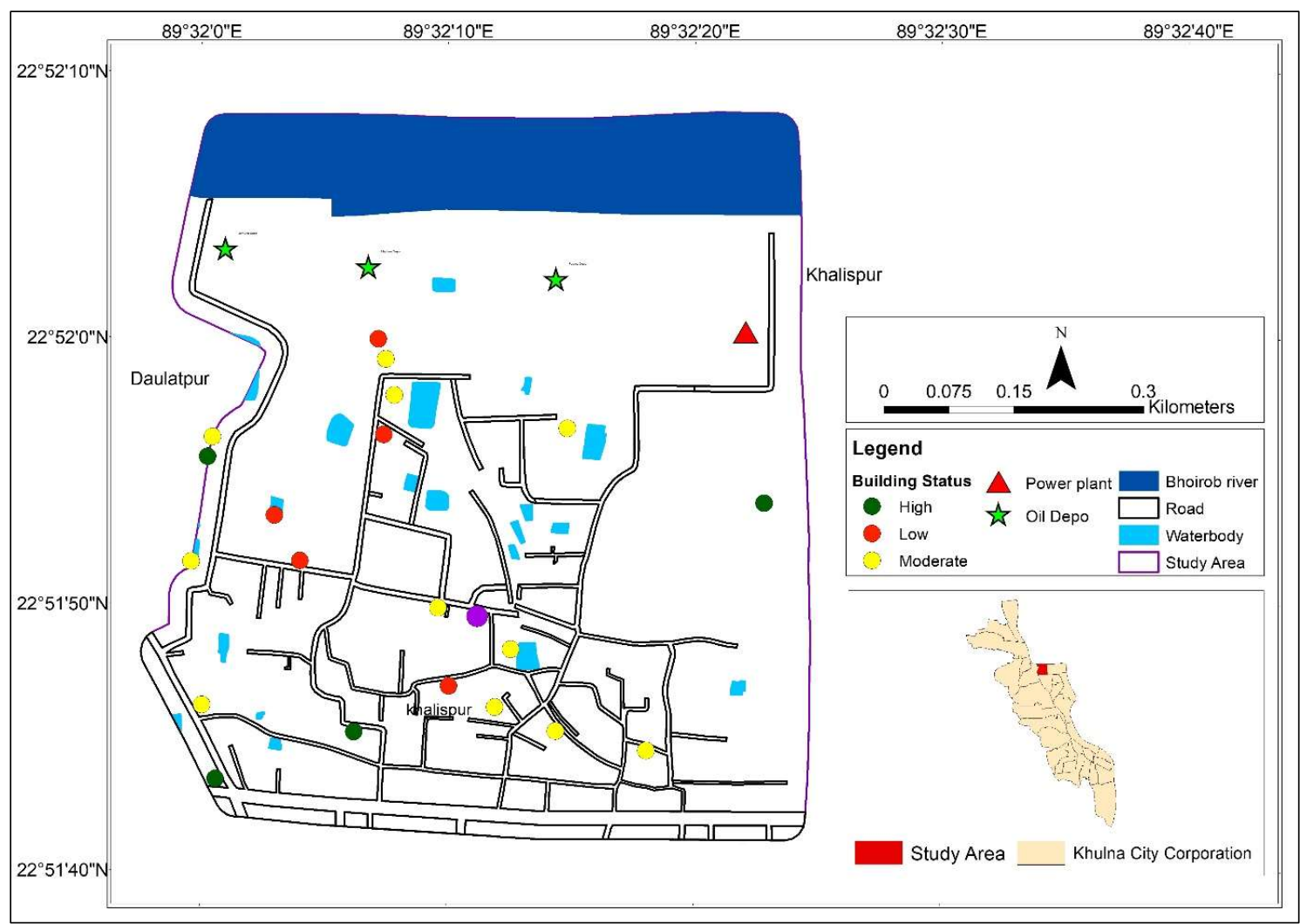

Figure 2: Fire Risk Level of 20 selected Building

\section{DISCUSSION}

From the findings of the study, it can be interpreted that distance from the oil depot or from the power station is not the only risk factor of accidental fire breakdown. Rather than that the surrounding landuse and the existing fire extinguishing system of the building play more vital role in deducting the risk level of the buildings. So, this helps use to figure out the importance of landuse zonal variances. Most of the studies regarding accidental fire breakdown of oil depots (Shi et al., 2014; Abbasi et al., 2014; Lin et al., 2012; Satoh et al., 2011) mainly concentrate on the structural design or management system of the oil depots i.e. they mainly try to determine the risk of fire breakdown inside the depots and its consequences. But this study tries to determine the risk of the surrounding residential areas and for this it also try to address all the smallest possible factors.

\section{CONCLUSION}

The study was focused on determining the risk of the general land-uses next to the risky land-uses in Ward no. 07 of Khulna City. Basically the objective was to display the ignorance towards maintaining the land-use zonal variance. The building located in the study area are under huge risk of fire hazard due to 3 oil depots and 2 power stations in the area. The oil depots creates a huge risk of masive fire explotion wherease the power stations add to the risk. The result found that $25 \%$ of the buildings are at low risk, $55 \%$ of them are at medium and $20 \%$ of the buildings are at an extreme risky condition. As the area is a well established and already developed as a mixed 
landuse, it is not possible overtime to change or relocate the landuses. Therefore to reduce the risk of fire hazard the precautions and preparedness are the only measures. For precaution the depots and power stations should assure strict rules to avoid triggering a fire hazard and should also have that preparedness to address a fire hazard at a primary stage. The local people needs to be enlightened about the risk and their current vulnerable situation and trained them about their roles and reactions during an accidental fire breakdown. Different govt. organizations like Khulna City Corporation, Khulna Development Authority (KDA), Fire Service Authority etc. can take initiatives to engage or encourage civil society to be involved in the maintenance and monitoring of different kind of fire safety measures.

\section{ACKNOWLEDGEMENT}

This is the extended version of the conference paper presented in ICCESD 2020. We wish to express our deepest thanks to the Town Planner, Khulna Development Authority, Khulna, Councilor of Ward 07, Khulna City Corporation, Khulna, the officials of Khalispur Fire Station,Khulna, the officials of Padma, Meghna and Jamuna Oil Depot, Khulna as well as the local peovhjhfgple of the Ward for providing data and information and for their assistance in this study.

\section{REFERENCES}

Atkinson, G. (2014). Buncefield: Lessons learned on emergency preparedness. Loss Prevention Bulletin 254, $23-$ 28.

Abbasi, M. H., Benhelal, E., and Ahmad, A. (2014). Designing an Optimal Safe Layout for a Fuel Storage Tanks Farm: Case Study of Jaipur Oil Depot. International Journal of Chemical, Molecular, Nuclear, Materials and Metallurgical Engineering, 8(2), 147-155.

Bangladesh Bureau of Statistics. (2001). Bangladesh Population Census. Bangladesh Bureau of Statistics.

Bangladesh Fire Service and Civil Defense . (2018). Annual Report 2018. Dhaka: People's Republic of Bangladesh.

Biswas, C., and Haque, S. M. (2019). Developing Planning Solutions For Managing Fire Risks Considering Spatial Variation Of The Risk Of Fire: A Case Study Of Khulna City. International Conference on Disaster Risk Management. Dhaka, Bangladesh.

Bukowski, R. (1996). Risk and performance standards,. Gaithersburg, USA: Institute of Standards and Technology.

Camanho, R., and Russo, R. d. (2015). Criteria in AHP: A Systematic Review of Literature. Science direct.

Cardona, O.-D., Aalst, M. K., Birkmann, J., Fordham, M., McGregor, G., Perez, R., . . Sinh, B. T. (2012). 2012: Determinants of risk: exposure and vulnerability. In: Managing the Risks of Extreme Events and Disasters to Advance. Cambridge, UK, and New York, NY, USA: Cambridge University Press.

Deely, S., Dobman, D., Hardoy, J., Johnson, C., Satterthwaite, D., Serafin, A., and Waddinton, R. (2010). World Disaster Report. Zurich: International Federation of Red Cross and Red Crescent Societies.

(2014). Disaster Report 2013. Dhaka: Department of Disaster Management, Ministry of Disaster Management and Relief, Government of the.

Frantzich, H. (1998). "Risk analysis and fire safety. Fire Safety Journal.

Hadjisophocleous, G. (2003). Literature Review of Fire Risk Assessment Methodologies. International Journal on Engineering Performance-Based Fire Code, 23-45.

Haque, M. N., Srestho, M. A., and Siddika, S. (2021, May). Suitable Locations for Industrial Setup in Urban Context: Way Forward To Meet the SDGs for Khulna City, Bangladesh. International Journal of Built Environment and Sustainability, 8(2).

Hossain, S. Z. (2019, February 26). Fire incidents in Bangladesh triple over 22 years. Retrieved from DhakaTribune: $\quad$ https:/www.dhakatribune.com/bangladesh/nation/2019/02/26/fire-incidents-inbangladesh-triple-over-22-years

Hu, X., Wu, Z., Hedlund, F. H., Pedersen, B. J., Wang, R., Yingquan, D., and Sin, G. (2018). Land-use planning risk estimates for a chemical industrial park in China - A longitudinal study. Process Safety Progress, 37(2), 124-133. doi:10.1002/prs.11972

Imam, H. (2010, June 10). Nimtoli tragedy: The worst nightmare. Retrieved from The Daily Star: https://www.thedailystar.net/news-detail-142316

International Federation of Red Cross and Red Crescent Societies . (2016). World Disaster Report 2016.

Islam, M. M., and Adri, N. (2008, June). Fire Hazard Management of Dhaka City: Addressing Issues Relating to Institutional Capacity and Public Perception. Jahangirnagar Planning Review, 6, 57-67.

Islam, M. Z., and Hossain, K. M. (2018). Fire Hazards in Dhaka City: An Exploratory Study on Mitigation Measures. IOSR Journal of Environmental Science, Toxicology and Food Technology, 46-56. 
Keane, R. E., Drury, S. A., Karau, E. C., Hessburg, P. F., and Reynoids, K. M. (2008, December 26). A method for mapping fire hazard and risk across multiple scales and its application in fire management. Ecological Modelling, 2-18. doi:10.1016/j.ecolmodel.2008.10.022

Lin, S., Yi, P., and Shuangchun, Y. (2012, November). The Cause of Fire and Preventive Measures in Oil Depot. International Journal of Engineering Research and Development, 4(11), 55-57.

Meacham, B., Charters, D., Johnson, P., \& Salisbury, M. (2016). Building fire risk analysi. FPE Handbook of Fire Protection Engineering, 2941-2991. doi:https://doi.org/10.1007/978-1-4939-2565-0_75

Roy, T. K. (2013). A Report on Collection and Review of Secondary Information for Formulation Phase of the Fecal Sludge Management (FSM) Project in Bangladesh.

Sakib, N., Islam, S., Ali, K. M., and Ansary, M. A. (2010, December). Fire Safety Survey of High-rise Buildings in Chittagong City. Journal of South Asian Disaster Studies, 3(2), 81-94.

Satoh, K., Liu, N., Xie, X., Zhou, K., Chen, H., Wu, J., Lei, J., Lozano, J. S. (2011). CFD Study of Huge Oil Depot Fires - Generation of Fire Merging and Fire Whirl in Arrayed Oil Tanks. Fire safety Science (pp. 693-706). International Association for Fire Safety Science. doi:10.3801

Shi, L., Shuai, J., and Xu, K. (2014, June). Fuzzy fault tree assessment based on improved AHP for fire and explosion accidents for steel oil storage tanks. Journal of Hazardous Materials, 529-538.

UNDRR. (2017). PreventionWeb. Retrieved from Sendai Framework: https://www.preventionweb.net/disasterrisk/risk/vulnerability

UNNOSA. (2019). Disaster Risk Management. Retrieved from Knowledge Portal: http://www.unspider.org/risks-and-disasters/disaster-risk-management

Watts, J., \& Hall, J. (2002). Introduction to fire risk analysis. SFPE Handbook of Fire Protection, (pp. 1-5). Quincy, MA,.

Zhou, Y., Zhao, X., Zhao, J., and Chen, D. (2016). Research on Fire and Explosion Accidents of Oil Depots. Chemical Engineering Transactions.

(C) 2021 the Authors. Journal of Engineering Science published by Faculty of Civil Engineering, Khulna University of Engineering \& Technology. This is an open access article under the terms of the Creative Commons AttributionNonCommercial-NoDerivatives License, which permits use and distribution in any medium, provided the original work is properly cited, the use is non-commercial and no Modifications or adaptations are made. 